\section{Scholarships for Scientific Initiation Encourage Post-Graduation Degree}

Gabriela S. Pinto ${ }^{1}$, Gustavo G. Nascimento ${ }^{1}$, Matheus S. Mendes ${ }^{1}$, Fabrício A. Ogliari', Flávio F. Demarco ${ }^{1,2}$, Marcos B. Correa ${ }^{1}$

This study aimed to evaluate the factors associated with the decision to attend an academic post-graduation program by dental students. A cross-sectional study was conducted in 2012, last-year undergraduate students from Dental Schools of Southern Brazil. A closed questionnaire was applied including questions grouped in three different blocks: pre-graduate, undergraduate period and future perspectives. The outcome was the decision to pursuit an academic post-graduation degree. Associations were tested using chi-squared test and chi-squared test for linear trends when appropriate. Multivariate Poisson regression was also performed. The sample was composed by 671 students (response rate of $69.9 \%, n=467$ ). In relation to future perspectives, $68 \%$ of the interviewed students intended to attend a post-graduation program, but only $17.5 \%$ would choose a program with academic and research post-graduation program (Master and $\mathrm{PhD}$ programs). In the final model, students from public universities (PR 2.08, 95\% $\mathrm{Cl}$ $1.41-3.08$ ) and students that received scientific initiation scholarship (PR $1.9395 \% \mathrm{Cl}$ 1.14-3.27) presented a twice greater prevalence to seek academic post-graduate programs. Students with higher family incomes showed a lower prevalence to seek these programs (PR 0.50, 95\% IC 0.28-0.90). Scholarships seem to encourage undergraduate students to pursue stricto sensu post-graduation.

\author{
'Graduate Program in Dentistry, \\ UFPel - Federal University of \\ Pelotas, Pelotas, RS, Brazil \\ ${ }^{2}$ Graduate Program in Epidemiology, \\ UFPel - Federal University of \\ Pelotas, Pelotas, Pelotas, RS, Brazil \\ Correspondence: Dr. Marcos Britto \\ Correa, Rua Gonçalves Chaves, 457, \\ s. 506, 96015-560 Pelotas, RS, Brasil. \\ Tel: +55-53-3225-6741. e-mail: \\ marcosbrittocorrea@hotmail.com
}

\section{Introduction}

Brazil has more than 200 Dental Schools, with the largest dentists/total population ratio in the world (1). Historically, Brazilian dental education has been based on transmitting knowledge focused on dental diseases and techniques rather than the needs of the Brazilian population and the dental educators, most of whom were practitioners rather than teachers, have been primarily oriented towards manual training. Traditionally, professional training focused on a private clinic model that is unaffordable to most Brazilians and thus leads to an unacceptable overall oral epidemiological profile (2).

In the last decades, Brazil has experienced a significant growth in research activities in all areas of knowledge and became an important producer of scientific knowledge (3). The number of post-graduation programs had an exponential growth in Brazil and this was also observed in Dentistry (4). To maintain the status of a respected scientifically based health profession, with a practice based on evidence, dentistry must be updated combining the scientific and technological advances within its educational and patient care systems (5).

The curriculum reorganization in Dental Schools also emphasized the need for an earlier contact with research during the undergraduate course, since scientific methodology could produce a favorable impact in the dentist formation. Some studies observed benefits from such approach, like integration of biomedical/biodental clinical sciences, scholarly approaches to evidence-based paradigms in clinical patient management, and application of biomedical/biodental technological advances to clinical practice settings (6). An early contact with scientific research seems to be beneficial for the dental profession in other parts of the world and impact positively the decision to pursue a career in academic dentistry (7).

Studies exploring the profile of the students provide valuable information for the planning of educational policies and strategies, in addition to qualifying the faculty on issues related to education. However, there is a lack of studies investigating the reasons that lead dental students to seek an academic post-graduation program after completing graduation. Therefore, this study aimed to evaluate the factors associated with dental students' decision to attend an academic post-graduation program to obtain a Master's or PhD degree in Southern Brazil.

\section{Material and Methods}

This is an observational cross-sectional study conducted in 2012, with last-year dental students from the state of Rio Grande do Sul, in the southern region of Brazil. All dental schools located in the state $(n=13)$ were invited to participate. However, from this total, only 10 presented a last-year class in 2012, and out of these, 9 accepted the invitation. Ethical approval to conduct the study was granted by the Ethics Committee of the Medical School of the Federal University of Pelotas (Registration number 
34/2012).

Subjects signed written informed consent after the purpose and the procedures of the study were carefully explained. Questionnaires were administered in the classrooms to all participants by one trained instructor, who visited each city where the dental schools were located, in the second semester of 2012. The questionnaire was selfapplicable and consisted of closed questions grouped in three different blocks: pre-graduate period, undergraduate period and future perspectives. The dependent variable considered for this study was the intent of the students to pursue an academic post-graduation degree (Master's degree or a $\mathrm{PhD}$ degree).

Questions of the pre-graduate period were related to socioeconomic and demographic profile of students: age, gender, skin-color (white and non-white), family income [Brazilian Reals (BRL), divided in tertiles] and knowledge of a foreign language. Questions of the undergraduate period were related to type of university (public or private) and some type of scholarship funding (research, clinical advisory). In the future perspectives block, intents of seeking a graduate program (clinical specialization or research $\vec{\sigma}$ program) and field of interest were also asked. Still in this block, perceptions of students about the value of dental procedures were assessed.

The software STATA version 12.0 (Stata Corporation; College Station, TX, USA) was used for the analysis. Descriptive analysis was made to assess the distribution of pursuing an academic graduate program related to other independent variables. Associations between variables were tested using chi-square test and chi-square test for linear trends as appropriate. Multivariate Poisson regression with robust variance was used to test the association between the outcome and independent variables adjusting for potential confounders. For variable selection the stepwise method with backward selection was used. Variables with $p<0.20$ were included in the final model, and estimated their Prevalence Ratio (PR) and their 95\% interval of confidence.

\section{Results}

From the 671 students enrolled in the last year of graduation in the 9 Dental Schools, 467 answered the questionnaire, corresponding to a response rate of $69.9 \%$. Mean age of students was 24.8 $\left(\mathrm{SD}_{ \pm} 4.3\right)$ years, with a total of $69 \%$ of female, and $96 \%$ self-declared white skin. The average family income was $7,740.00( \pm 7,072)$ BRL. In relation to future perspectives, about $68 \%$ of the sample intends to pursue a graduate program. However, only 17.5\% want to join an academic and research program (Master and $\mathrm{PhD}$ programs). Table 1 presents distribution data of students who claimed to pursue an academic degree with independent variables. Studying in a public university, knowing foreign language, receiving a research scholarship (Scientific Initiation Scholarship) and considering as low the values paid for dental procedures, were associated with the intent for seeking an academic degree.

Figure 1 shows the dental specialties preferred by students who intend to seek an academic degree. Endodontics was the most preferred specialty followed by Dental Prosthodontics and Operative Dentistry. Table 2 presents information about the most cited dental specialties separated by type of course (clinical specialization versus academic career). As displayed in this table, in all the

Table 1. Sample distribution according to choice for an academic graduate program and independent variables. Absolutes $(n)$ and relatives $(\%)$ frequencies. Pelotas, RS, Brazil, 2012 ( $\mathrm{n}=467)$

\begin{tabular}{|c|c|c|c|}
\hline $\begin{array}{l}\text { Independent } \\
\text { variables }\end{array}$ & $\begin{array}{c}\text { Stricto sensu } \\
\text { graduate course (\%) }\end{array}$ & Total & $\begin{array}{c}\mathrm{p} \\
\text { value }\end{array}$ \\
\hline \multicolumn{4}{|l|}{ Gender } \\
\hline Male & $25(17.5)$ & 143 & \multirow{2}{*}{0.943} \\
\hline Female & $57(17.8)$ & 321 & \\
\hline \multicolumn{4}{|l|}{ Age } \\
\hline $20-25$ & $68(19.7)$ & & \multirow{2}{*}{0.063} \\
\hline$>25$ & $14(12.1)$ & 345 & \\
\hline \multicolumn{4}{|l|}{ Skin color } \\
\hline White & $80(18.0)$ & 444 & \multirow{2}{*}{0.402} \\
\hline Non white & $2(10.5)$ & 19 & \\
\hline \multicolumn{4}{|c|}{ Family income (tertiles) } \\
\hline 1 & $24(23.3)$ & 83 & \multirow{3}{*}{0.078} \\
\hline 2 & $18(17.0)$ & 79 & \\
\hline 3 & $13(13.7)$ & 91 & \\
\hline \multicolumn{4}{|c|}{ Type of University } \\
\hline Public & $43(26.7)$ & 161 & \multirow{2}{*}{$<0.001$} \\
\hline Private & $39(12.8)$ & 305 & \\
\hline \multicolumn{4}{|c|}{ Scholarship during graduation } \\
\hline Yes & 25 (21.9) & 118 & \multirow{2}{*}{0.236} \\
\hline No & $57(16.4)$ & 348 & \\
\hline \multicolumn{4}{|c|}{$\begin{array}{l}\text { Scholarship for research } \\
\text { during gradutaion }\end{array}$} \\
\hline Yes & $20(35.9)$ & 57 & \multirow{2}{*}{$<0.001$} \\
\hline No & $21(18.1)$ & 116 & \\
\hline \multicolumn{4}{|c|}{ Knowledge of a foreign language } \\
\hline Yes & $57(22.5)$ & 253 & \multirow{2}{*}{0.002} \\
\hline No & $24(11.6)$ & 208 & \\
\hline \multicolumn{4}{|c|}{$\begin{array}{l}\text { Opinion about dental } \\
\text { procedures values }\end{array}$} \\
\hline Good & $12(13.5)$ & 89 & \multirow{3}{*}{0.027} \\
\hline Regular & 41 (15.6) & 258 & \\
\hline Bad & $29(24.8)$ & 117 & \\
\hline
\end{tabular}


Table 2. Distribution of last year dental school who pursue a Postgraduate Program according to type of course and most cited dental specialties. Pelotas, RS, Brazil, 2012 ( $n=268)$

\begin{tabular}{lccc}
\hline \multirow{2}{*}{ Dental specialty } & \multicolumn{3}{c}{ Graduate Program } \\
\cline { 2 - 4 } & Lato sensu & Stricto Sensu & Total \\
\hline Orthodontics & $60(85.7)$ & $10(14.3)$ & 70 \\
Endodontics & $38(74.5)$ & $13(25.5)$ & 51 \\
Oral and Maxillofacial & $40(85.1)$ & $07(14.9)$ & 47 \\
Surgery & $33(75.0)$ & $11(25.0)$ & 44 \\
Dental Prosthodontics & $34(91.9)$ & $03(8.1)$ & 37 \\
Implantology & $15(78.9)$ & $04(21.1)$ & 19 \\
Pediatric Dentistry & & & \\
\hline
\end{tabular}

Table 3. Crude (b) and adjusted (a) prevalence ratio for graduate program and independent variables in last year dental students. Pelotas, RS, Brazil, 2012

\begin{tabular}{|c|c|c|c|c|}
\hline $\begin{array}{l}\text { Independent } \\
\text { variables }\end{array}$ & RPb(1C 95\%) & $\begin{array}{c}\mathrm{p} \\
\text { value }\end{array}$ & $\mathrm{RPa}(1 \mathrm{C} 95 \%)$ & $\begin{array}{c}\mathrm{p} \\
\text { value }\end{array}$ \\
\hline \multicolumn{5}{|l|}{ Gender } \\
\hline Male & 1 & \multirow[t]{2}{*}{0.943} & \multirow[t]{2}{*}{-} & \multirow[t]{2}{*}{-} \\
\hline Female & $1.01(0.66-1.55)$ & & & \\
\hline \multicolumn{5}{|l|}{ Age } \\
\hline $20-25$ & 1 & \multirow[t]{2}{*}{0.070} & 1 & \multirow[t]{2}{*}{0.069} \\
\hline$>25$ & $0.61(0.35-1.04)$ & & $0.58(0.32-1.04)$ & \\
\hline \multicolumn{5}{|l|}{ Skin Color } \\
\hline White & 1 & \multirow[t]{2}{*}{0.427} & \multirow[t]{2}{*}{-} & \multirow[t]{2}{*}{-} \\
\hline Non-white & $0.58(0.15-2.22)$ & & & \\
\hline \multicolumn{5}{|c|}{ Family income (tertiles) } \\
\hline 1 & 1 & \multirow{3}{*}{0.076} & 1 & \multirow{3}{*}{0.021} \\
\hline 2 & $0.72(0.42-1.26)$ & & $0.73(0.41-1.31)$ & \\
\hline 3 & $0.58(0.31-1.08)$ & & $0.50(0.28-0.90)$ & \\
\hline \multicolumn{5}{|c|}{ Type of University } \\
\hline Private & 1 & \multirow[t]{2}{*}{$<0.001$} & 1 & \multirow[t]{2}{*}{0.019} \\
\hline Public & $2.08(1.41-3.08)$ & & $1.80(1.10-2.95)$ & \\
\hline \multicolumn{5}{|c|}{ Scholarship during graduation } \\
\hline No & 1 & \multirow[t]{2}{*}{0.008} & \multirow[t]{2}{*}{-} & \multirow[t]{2}{*}{-} \\
\hline Yes & $1.70(1.15-2.52)$ & & & \\
\hline \multicolumn{5}{|c|}{ Research scholarship } \\
\hline during graduc & & \multirow[t]{2}{*}{0.014} & & \multirow[t]{2}{*}{0.012} \\
\hline $\begin{array}{l}\text { INo } \\
\text { Yes }\end{array}$ & $1.93(1.14-3.27)$ & & $1.86(1.14-3.04)$ & \\
\hline \multicolumn{5}{|c|}{ Knowledge of a } \\
\hline No & 1 & \multirow[t]{2}{*}{0.003} & 1 & \multirow[t]{2}{*}{0.196} \\
\hline Yes & $1.95(1.25-3.03)$ & & $1.40(0.83-2.37)$ & \\
\hline \multicolumn{5}{|c|}{$\begin{array}{l}\text { Opinion about dental } \\
\text { procedures values }\end{array}$} \\
\hline Good & 1 & \multirow[t]{3}{*}{0.032} & 1 & \multirow[t]{3}{*}{0.114} \\
\hline Regular & $1.17(0.64-2.14)$ & & $1.10(0.55-2.17)$ & \\
\hline Poor & $1.83(0.99-3.39)$ & & $1.69(0.82-3.45)$ & \\
\hline
\end{tabular}

Analysis by Poisson's Regression. specialties prevailed the choice for clinical specialization. Even in the preferred options for academic career (Endodontics and Dental Prosthesis), almost three quarters of the students declared an intention to follow clinical specialization.

Results from the crude and adjusted multivariate Poisson regression are presented in Table 3 . In the final model, students from public universities (PR 2.08, 95\% Cl 1.41-3.08) and students who received research scholarship (PR 1.93, 95\% $\mathrm{Cl} 1.14-3.27$ ) presented prevalence twice as large to seek a post-graduation academic program than did students from private schools and students who did not receive any financial support for research during graduation. Moreover, students from the highest tertile of familiar income presented 50\% lower prevalence of pursuing an academic graduate program than students from the lower tertile of income (PR 0.50, 95\% IC 0.28-0.90).

\section{Discussion}

The present study investigated factors associated with pursuing an academic post-graduation course among last-year dental students from Southern Brazil. The findings demonstrated that, after adjustment for confounding factors, the outcome was associated with lower family income, studying at public university and being part of a research program during the graduate course. It is important to emphasize this type of investigation is still scarce, even with the increase of investments in post-graduate programs in Brazil.

This study found that almost one fifth of the last year dental students want to join an academic and research program (Master and PhD programs). In Brazil, these types of post-graduate programs differ completely from specialization courses because they are more focused on forming dental educators and researchers rather than specialist clinical practitioners (8). Even though, Brazilian dentists could attend a Master degree in order to apply for competitive jobs, where an academic degree may be decisive (9). In a study to compare the perspectives of dental students towards their career choice, it was found that 19\% of Swedish students indicated their future career as educator 
(10), which is in agreement with the present findings. Analyzing how residents who intend to enter private practice versus academic careers differ in their background and educational characteristics, Lanzon et al. (11) explained that one could speculate that the different perceptions between academicians and clinicians in private practice might not affect career decision-making to a great extent because overall the salaries of both might be seen as sufficient to live a comfortable life in United States.

In relation to the field of interest targeted by last year dental students, the findings revealed that the clinical fields are predominant. The interest for post-graduation courses at specialization levels was greater than the academic programs (Master or $\mathrm{PhD}$ ). Being a teacher at a Dental School can also be considered as a promising career in Brazil. However, the financial benefits obtained in some specialties, such as Orthodontics, Endodontics and Oral and Maxillofacial Surgery, in clinical practice could be significantly greater than those received by dentists in an academic career, which, though, carries a "greater social status" in the society.

The governments worldwide are developing strategies to increase the amount of dental researchers/educators, in practice $(12,13)$.

Brazilian government has increased the funding for public universities expansion in order to improve the amount of individuals with a college degree in the society. However, in relation to dental education, the expansion was predominantly directed to new private schools, which generally charge high monthly fees from individuals aiming to obtain a DDS degree. It has been reported that most of the private school graduate students aim to have their own dental clinics (3). Private education reduces the appeal of career development because most of these schools provide a full-time curriculum and lack integration with biological/ research and clinical sciences $(12,13)$. In addition, one fact that may explain the association between type of school and pursuing a post-graduate program is the difference between dental educator's career in private and public schools in Brazil. Most of the professionals working in public institutions are tenured to the school in full time, allowing them more time dedicated to research. On the other hand, educators from private institutions, where most positions for students are available (14), have a parttime dedication to teach and complement their income in private dental practice.

The findings of present study also showed a positive relationship between receiving a Scientific Initiation (SI) scholarship and search for post-graduate academic training. Brazilian science has experienced a boom in the last few decades, and some reasons pointed out to justify this

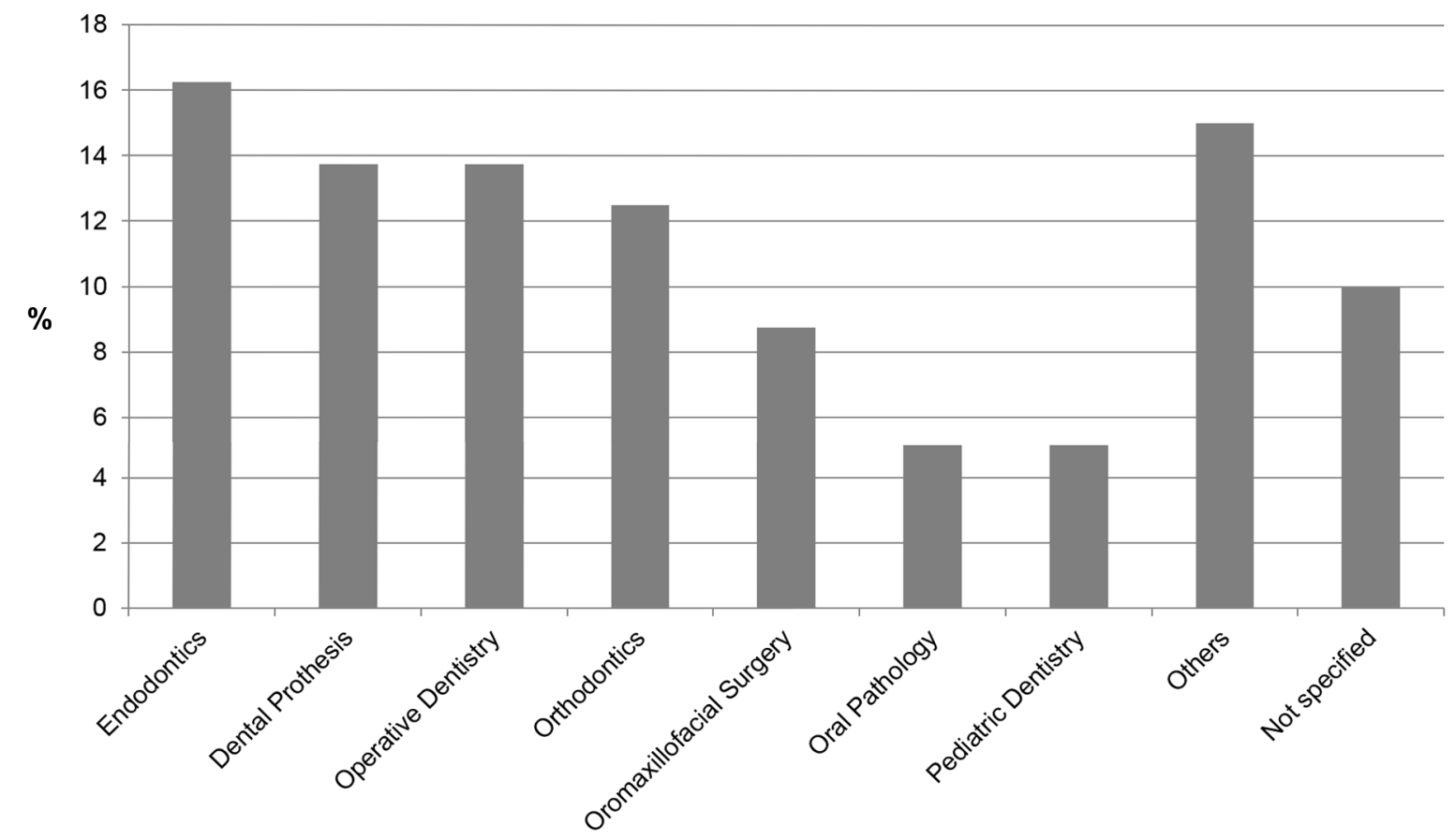

Figure 1. Distribution (\%) of dental specialties of greatest interest for academic graduate courses among Brazilian last-year dental students. Pelotas, RS, Brazil, 2012. 
boom are related to the country' economic growth, the increased availability of funding for research, expansion of the post-graduation programs and international research exchanges and partnerships (3). Also, the Program for Scientific Initiation, which offers scholarships for students during their graduation courses, has been reported as a crucial reason for the development of science in Brazil. This Scientific Initiation program has experienced an exponential growth, mostly supported by the Federal Government funding agency (CNPq) and by States' funding agencies (FAPs) and the principal aim of this scholarship is to encourage and train students for the Master and $\mathrm{PhD}$ programs (3). Based on these findings, it seems reasonable to assume that such objective is indeed being achieved, at least in Brazilian Dental Schools. Notably, scientific research in Brazil is mainly developed in public universities, so the number of Scientific Initiation Scholarships available for public universities is larger than those available for private universities (3). When evaluating the number of researchers receiving productivity scholarships, it was found that more than $90 \%$ of those receiving these scholarships were in a public university (4).

The literature related to the reasons for a student to pursue an academic career is scarce. Many reasons may lead graduate students to continuing education. First of all, it stimulates a scape from the traditional curriculum and routine, with an approach with professors and academic matters that seem more attractive. Most of the times, the student may also choose his/her academic advisor. Consequently, contact with professors is different, allowing a more personal approach with a less vertical relationship and a non-infallible perception of the advisors. With a closer contact, the advisor can use different teaching strategies, showing how to read a paper, to improve manual skills or to speak in public. Another positive point is the contact with information, learning how to search for updates and relevant references. Fava and Fava (15) stated that students involved in Scientific Initiation presented better results in post-graduate selections, with a shorter time for finishing their thesis and better team spirit, and also an easier employability due to their different skills was observed. A recent study showed additionally that programs that introduce students to academic careers through teaching assistant positions, fellowship and peer tutoring opportunities are valuable ways to improve the faculty student ratio, to enhance learning for both the teaching assistants and their students, and to introduce the idea of a future career in academia to those who may never have considered this possibility (16). A study in India, for example, showed that introducing research into the curriculum would be one of the three key pivotal aspects that might bring dental education to a higher level in that country, in addition to selecting highly motivated students for dentistry and modifying the teaching methodology with some importance given to treatment planning (17).

The fact that the students from the last tertile (wealthier students) are less prone to pursue an academic degree/ career could be related to the general idea that these academic positions will have worse remuneration, with lower socioeconomic status. Indeed, this could also be due to the fact that individuals attending dental school are not well informed about the dentistry market situation nowadays in Brazil, which represents 19\% of the world workforce. It seems that students entering in the Dental Schools or even those concluding the course are still with a social presentation based on past decades, with the dentists working only in private practice with huge financial earnings, which, in general, is not the actual reality for the profession in Brazil.

There is a great effort ongoing to investigate the bibliometric production in Dentistry (17-20), so the understanding of the individuals' wishes and fields of interest in early stages could contribute to enhance their ability for research and ultimately impact on Brazilian scientific production in Dentistry, which has already presented a significant growth (21).

Is summary, in the present study, students from families of lower socioeconomic level and those attending undergraduate dental courses in public universities are more prone to pursue an academic career. Scientific Initiation scholarships also seem to encourage undergraduate students to seek stricto sensu post-graduation programs. The present findings provide encouraging evidence that financial support for conducting research during graduation can reflect in future professional aspirations, which may result in more critical professionals in both clinical and academic environment. Additionally, it is plausible that students more enrolled in research activities during undergraduate period will have more involvement with continuum education and a scientific based clinical practice (22). Moreover, the obtained data could be used for planning public policies for human resources development in Brazil.

\section{Resumo}

Este estudo objetivou avaliar os fatores associados com a decisão de estudantes de Odontologia em participar de um programa de pósgraduação acadêmica. Um estudo transversal foi conduzido em 2012, com estudantes do último ano do curso de Odontologia do Sul do Brasil. Foi aplicado um questionário fechado composto por três diferentes blocos: período prévio à graduação, período da graduação e perspectivas futuras. 0 desfecho deste trabalho foi definido como a decisão de buscar uma pós-graduação acadêmica. As associações foram testadas com o teste de Qui-quadrado e de Qui-quadrado de tendência linear, quando apropriado. Além disso, foi feita a regressão multivariada de Poisson. A amostra foi composta por 671 estudantes (taxa de resposta de 69,9\%, n=467). Em relação às perspectivas futuras, $68 \%$ dos estudantes entrevistados pretendem ingressar em um curso de pós-graduação, mas somente 17,5\% 
escolheriam um programa com pós-graduação acadêmica e pesquisa (Programas de Mestrado e Doutorado). No modelo final, estudantes de universidades públicas (RP 2,08,95\% Cl 1,41-3,08) e estudantes que receberam bolsa de iniciação científica (RP 1,93 95\% Cl 1,14-3,27) apresentaram prevalência duas vezes maior na busca de pós-graduação acadêmica. Estudantes de familias com renda alta mostraram menor prevalência na busca destes cursos (RP 0,50,95\%lC 0,28-0,90). Desta forma, bolsas parecem incentivar os alunos de graduação na busca por pós-graduação stricto sensu.

\section{Acknowledgements}

The authors would like to thank the research funding agencies CAPES and FAPERGS for the scholarships granted to the post-graduate students participating in the study. They would also like to thank the Deans of the nine Dental Schools that allowed the interviews to be carried out.

\section{References}

1. American Student Dental Association. American Student Dental Association. Available from: http://www.asdanet.org/uploadedFiles/ FDI\%20World\%20Federation\%20Dental\%20schools\%20list $\% 20$ 10\%20Dental\%20Schools.pdf. Latest access: Mar 14, 2014.

2. Chaves SC. Oral health in Brazil: the challenges for dental health care models. Braz Oral Res 2012;26-s1:71-80.

3. Guimarães JA. Medical and biomedical research in Brazil. A comparison of Brazilian and international scientific performance. Cienc Saúde Colet 2004;9:303-327.

4. Scarpelli AC, Sardenberg F, Goursand D, Paiva SM, Pordeus IA. Academic trajectories of dental researchers receiving CNPq's productivity grants. Braz Dent J 2008;19:252-256.

5. lacopino AM, Pryor ME, Taft TB, Lynch DP. The effect of NIDCR R25 grant support on the curriculum and culture of a research nonintensive dental school. J Dent Res 2007;86:581-585.

6. Almeida-Filho N. Higher education and health care in Brazil. Lancet 2011;377:1898-1900.

7. Pucca GA, Lucena EHG, Cawahisa PT. Financing national policy on oral health in Brazil in the context of the Unified Health System. Braz Oral Res 2010;24:26-32.

8. Brazilian Ministry of Education's Federal Agency for Support and Evaluation of Graduate Education (CAPES). Directory of Evaluation - DAV. Available from: http://www.capes.gov.br/images/stories/
download/avaliacao/ODONTOLOGIA17dez09.pdf. Latest access: April 3, 2014.

9. Saliba NA, Moimaz SA, Garbin CA, Diniz DG. Dentistry in Brazil: its history and current trends. J Dent Educ 2009;73:225-231.

10. Karibe H, Kawakami T, Suzuki A, Warita S, Ogata K, Aoyagi K, et al. Career choice and attitudes towards dental education amongst dental students in Japan and Sweden. Eur J Dent Educ 2009;13:80-86.

11. Lanzon J, Edwards SP, Inglehart MR. Choosing academia versus private practice: factors affecting oral maxillofacial surgery residents career choices. J Oral Maxillofac Surg 2012;70:1751-1761.

12. Bertolami CN. The role and importance of research and scholarship in dental education and practice. J Dent Educ 2002;66:918-924.

13. Stashenko P, Niederman R, DePaola D. Basic and clinical research: issues of cost, manpower needs, and infrastructure. J Dent Educ 2002;66:927938.

14. lacopino AM. The influence of "new science" on dental education: current concepts, trends, and models for the future. J Dent Educ 2007;71:450-462.

15. Fava-de-Moraes F, Fava M. The scientific initiation: several advantages and few risks. São Paulo em Perspectiva. 2000;14:73-77.

16. McAndrew M, David Brunson W, Karanjit Kamboj BA. A survey of U.S. Dental School programs that help students consider academic careers. J Dent Educ 2011;75:1458-1464.

17. Elangovan S, Allareddy V, Singh F, Taneja P, Karimbux N. Indian dental education in the new millennium: challenges and opportunities. J Dent Educ 2010;74:1011-1016.

18. Feijoo JF, Limeres J, Fernández-Varela M, Ramos I, Diz P. The 100 most cited articles in dentistry. Clin Oral Investig 2014;18:699-706.

19. Poletto VC, Faraco Junior IM. Bibliometric study of articles published in a Brazilian journal of pediatric dentistry. Braz Oral Res 2010;24:83-88.

20. Sadeghi M, Shahravan A, Haghdoost AA, Asgary S, Rad M. Trend in dental research output in Iran over a period of 20 years (1990-2009). Int Dent J 2012;62:84-89.

21. Cury JA. The evolution of dental research in Brazil. Braz Oral Res 2004;18:97.

22. Nascimento GG, Correa MB, Opdam N, Demarco FF. Do clinical experience time and postgraduate training influence the choice of materials for posterior restorations? Results of a survey with Brazilian general dentists. Braz Dent J 2013;24:642-646.

Received October 22, 2013

Accepted January 28, 2014 